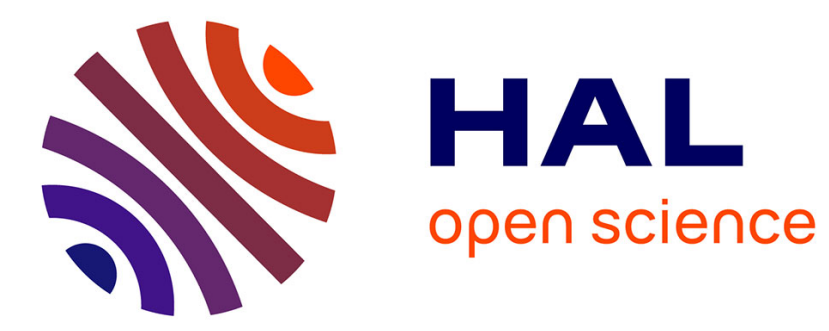

\title{
Application de la mécanique de la rupture a WC-Co
}

\author{
J.-L. Chermant, A. Deschanvres, A. Iost, R. Meyer
}

\section{To cite this version:}

J.-L. Chermant, A. Deschanvres, A. Iost, R. Meyer. Application de la mécanique de la rupture a WCCo. Revue de Physique Appliquée, 1974, 9 (4), pp.636-636. 10.1051/rphysap:0197400904063600 . jpa-00243829

\section{HAL Id: jpa-00243829 https://hal.science/jpa-00243829}

Submitted on 1 Jan 1974

HAL is a multi-disciplinary open access archive for the deposit and dissemination of scientific research documents, whether they are published or not. The documents may come from teaching and research institutions in France or abroad, or from public or private research centers.
L'archive ouverte pluridisciplinaire HAL, est destinée au dépôt et à la diffusion de documents scientifiques de niveau recherche, publiés ou non, émanant des établissements d'enseignement et de recherche français ou étrangers, des laboratoires publics ou privés. 


\title{
APPLICATION DE LA MÉCANIQUE DE LA RUPTURE A WC-Co
}

\author{
J.-L. Chermant, A. DESChANVRES, A. IOST
}

Groupe de Cristallographie et Chimie du Solide

Laboratoire de Chimie Minérale Industrielle, E.R.A., no 305

Université de Caen, 14032 Caen Cedex, France

et R. MEYER

Ugine Carbone, 54, avenue Rhin-et-Danube, 38100 Grenoble, France

Résumé. - Les méthodes de la mécanique de la rupture ont été appliquées à des matériaux fragiles et réfractaires tels que les carbures de tungstène-cobalt. Des essais de flexion trois points ont été effectués sur des éprouvettes entaillées pour déterminer l'énergie de fracture et la ténacité de ces matériaux. Les entailles ont été réalisées avec des meules diamantées en forme de «V $\mathrm{V}$ et/ou par électroétincelage avec des fils de tungstène de diamètre variant de $50 \mu \mathrm{m}$ à $1 \mathrm{~mm}$. Pour trois granulométries de carbure - 0,7,1 et 2,2 $\mu \mathrm{m}$ - les compositions en cobalt étudiées ont été les suivantes : $3 \%, 6 \%, 10 \%, 15 \%, 20 \%$ poids. Trois méthodes ont été employées pour déterminer l'énergie de fracture : la méthode analytique, celle de la compliance et celle de l'énergie de fracture.

La variation du facteur d'intensité de contrainte en fonction de la racine carrée du rayon à fond d'entaille indique que le facteur d'intensité de contrainte critique est atteint dans chaque cas. Par exemple pour WC-Co $15 \%$ avec un diamètre moyen de cristaux de carbure de $2,2 \mu \mathrm{m}$, la valeur de la ténacité est de $20 \pm 2 \mathrm{MPa} \sqrt{\mathrm{m}}$.

Pour un même diamètre de cristaux de carbure de tungstène, l'énergie de fracture et le facteur d'intensité de contrainte critique évoluent régulièrement en fonction de la fraction de cobalt. Par ailleurs pour une même fraction de cobalt, l'énergie de fracture et $K_{\text {IC }}$ évoluent régulièrement en fonction du diamètre moyen des cristaux de carbure, du moins dans l'intervalle $0,7-2,2 \mu \mathrm{m}$.

L'analyse des trajets de fracture sur des éprouvettes entaillées et non entaillées, par les méthodes d'analyse statistique, a permis de démontrer que pour une éprouvette non entaillée, le trajet de fracture est préférentiel alors que dans le cas d'une éprouvette entaillée, le trajet de fracture n'est pas préférentiel et est très rectiligne. Ceci démontre le caractère plan de la propagation de la fissure dans ces matériaux et est en parfait accord avec la variation linéaire de l'énergie de surface [1-2].

Abstract. - Fracture mechanics had been applied to the brittle and refractory materials tungsten carbide-cobalt, by a bend test on notched specimens in order to investigate the effective surface energy of crack initiation, $\gamma_{i}$, and the stress intensity factor. The notches were machined either with " V » diamond-whell and/or by the spark-erosion technique using tungsten wires of between $50 \mu \mathrm{m}$ and $1 \mathrm{~mm}$ in diameter. Three size distributions of carbide crystals $-0.7,1$ and $2.2 \mu \mathrm{m}$ - and several cobalt range : $3 \%, 6 \%, 10 \%, 15 \%, 20 \%$ weigh were investigated. Threet methods have been used to determine the effective surface energy : the analytical method, the compliance method and the work of fracture method.

For each material, the variation of $K_{I}$ as a function of the notch root radii indicates that the critical stress intensity factor is reached. For example for WC-Co $15 \%$ weight, with mean diameter of carbide crystals of $2.2 \mu \mathrm{m}$ the value of $K_{\mathrm{IC}}$ is $20 \pm 2 \mathrm{MPa} \sqrt{\mathrm{m}}$.

The variation of $\gamma_{i}$ and $K_{\mathrm{IC}}$ were studied as a function of the mean particle size diameter of carbide crystals and of the different cobalt volumic ratio, and one observes a regular evolution.

The analysis of fracture paths on notched and un-notched specimens had allowed using statistical analysis to indicate that the fracture path is preferential for un-notched specimens, while it is linear for notched specimens. That indicates the plane character of the rupture propagation in these materials, and is in complete agreement with the linear evolution of the surface energy [1-2].

[1] Chermant, J. L., Deschanvres, A., Iost, A., Meyer, R., Mat. Res. Bull. 8 (1973) 925.

[2] Chermant, J. L., Deschanvres, A., Iost, A., Symposium of « Fracture Mechanics of Ceramics », The Pennsylvania State University, University Park, Pennsylvania, July 11-13, 1973. 